\title{
Fundamental Rights Regimes in the European Union: Contouring Their Spheres
}

\author{
Ferdinand Wollenschläger
}

\section{Introduction}

Various fundamental rights regimes are in operation within the European Union (EU), and frequently overlap: national regimes, and in states which have a federal system even sub-national fundamental rights, the EU's fundamental rights and the European Convention on Human Rights (ECHR). This raises the issue of how to determine their respective scope of application, which is not only a substantive question, but also a procedural one since different courts are entrusted with their protection, notably the European Court of Justice (ECJ), the European Court of Human Rights (ECtHR), and national constitutional courts. It is also a sensitive and controversial question since conflicts of jurisdictions and institutions may and do arise: From a top-down perspective, and this has been confirmed by the experience in states which have a federal system such as the US or Germany, a far-reaching application of central fundamental rights catalogues may entail a significant unitarisation; and conversely, from a bottom-up perspective, applying decentral guarantees to EU action may endanger its uniform application.

Against this background, the first part of the paper (Sect. 2) explores the relevance of national fundamental rights for EU action. In this respect, a recent ruling of the German Bundesverfassungsgericht (Federal Constitutional Court-BVerfG)

\footnotetext{
The author holds a chair for Public Law, European Law and Public Economic Law at the Faculty of Law, University of Augsburg, Germany. Section 3 updates the author's contribution "The EU Charter of Fundamental Rights and its Applicability to the Member States-A Step towards Unitarisation or Federalisation?" published in: Ritsumeikan International Affairs 13 (2015), p. 1, the latter based on extracts of Wollenschläger (2014a).
}

F. Wollenschläger $(\bowtie)$

Chair for Public Law, European Law and Public Economic Law, Faculty of Law, Universität Augsburg, Universitätsstraße 24, 86159 Augsburg, Germany

e-mail: ferdinand.wollenschlaeger@jura.uni-augsburg.de 
on the European Arrest Warrant (of 15 December 2015) has shown that constitutional reservations (such as the famous "Solange" jurisprudence) are not only of theoretical, but also of practical relevance. The second part of the paper (Sect. 3) addresses the controversial question of the degree to which EU Member States are bound by EU fundamental rights, which in turn have finally been codified with the Treaty of Lisbon in 2009. Here, a potentially broad approach of the ECJ (notably Fransson case) contrasts with a somewhat restrictive position taken up by national constitutional courts.

\section{Delimitation of National and EU Fundamental Rights with Regard to EU Action}

While it is clear that EU action is comprehensively bound by EU fundamental rights (cf. only Art. 51 para. 1 CFR), ${ }^{1}$ the applicability of national fundamental rights to EU action remains controversial. ${ }^{2}$ There is however a need to distinguish between EU (Sect. 2.1) and national (Sect. 2.2) perspectives in this respect. This notwithstanding, an approximation between these two perspectives may be observed (Sect. 2.3).

\subsection{The EU Law Perspective}

Based on its understanding of EU law as an autonomous legal order, the ECJ rejects the (direct) applicability of national fundamental rights to EU action. The ECJ already held in its landmark ruling Costa/E.N.E.L. of 15 July 1964 "that the law stemming from the Treaty, an independent source of law, could not, because of its special and original nature, be overridden by domestic legal provisions, however framed, without being deprived of its character as Community law and without the legal basis of the Community itself being called into question." 3 In Internationale Handelsgesellschaft, a ruling handed down on 17 December 1970, the Court concretised this finding with regard to the protection of fundamental rights:

Recourse to the legal rules or concepts of national law in order to judge the validity of measures adopted by the institutions of the Community would have an adverse effect on the uniformity and efficacy of Community law. The validity of such measures can only be judged in the light of Community law. In fact, the law stemming from the Treaty, an independent source of law, cannot because of its very nature be overridden by rules of national law, however framed, without being deprived of its character as Community law

\footnotetext{
${ }^{1} \mathrm{Cf}$. in more detail, Wollenschläger (2014a), paras $56 \mathrm{ff}$.

${ }^{2}$ This section is based on Wollenschläger (2014a), paras $12 \mathrm{ff}$.

${ }^{3}$ ECJ, Case 6/64, Costa/E.N.E.L., [1964] ECR 587, 594.
} 
and without the legal basis of the Community itself being called in question. Therefore the validity of a Community measure or its effect within a Member State cannot be affected by allegations that it runs counter to either fundamental rights as formulated by the constitution of that State or the principles of a national constitutional structure. ${ }^{4}$

\subsection{The National Constitutional Law Perspective}

\subsubsection{Constitutional Conditions for European Integration}

There is however a differing national perspective on this issue. For, notwithstanding diverging approaches, national legal orders do not acknowledge the unconditional primacy of EU law and make primacy notably dependent on an adequate protection of fundamental rights. ${ }^{5}$ To take the German example, according to the well-known

\footnotetext{
${ }^{4}$ ECJ, Case 11/70, Internationale Handelsgesellschaft, [1970] ECR 1125, para 3 - while emphasising the role of national constitutional law as source of inspiration for EU fundamental rights, though (para 4). Cf. more recently ECJ, Case C-409/06, Winner Wetten GmbH, [2010] ECR I-8015, para 61; Case C-399/11, Melloni, EU:C:2013:107, para 59.
}

${ }^{5}$ See only for Denmark: Højesteret, 6 April 1998 - I 361/1997 (Maastricht), Nr. 9.2 (EuGRZ 1999, 49); France: Conseil Const., 20 December 2007 - 2007-560 DC (Lissabon), Nr. 9: "lorsque des engagements ... contiennent une clause contraire à la Constitution, remettent en cause les droits et libertés constitutionnellement garantis ou portent atteinte aux conditions essentielles d'exercice de la souveraineté nationale, l'autorisation de les ratifier appelle une révision constitutionnelle"; Art. 28 III Constitution of Greece; Italy: Corte Cost. ("Controlimiti-doctrine"), 27 December 1973 183/1973 (Frontini), Nr. 9 (EuGRZ 1975, 311); 5 June 1984 - 170/1984 (Granital), Nr. 7 (EuGRZ 1985, 98); 13 April 1989 - 232/1989 (Fragd); 18 April 1991 - 168/1991 (Giampaoli), Nr. 4: "l'ordinamento statale non si apre incondizionatamente alla normazione comunitaria giacché in ogni caso vige il limite del rispetto dei principi fondamentali del nostro ordinamento costituzionale e dei diritti inalienabili della persona umana, con conseguente sindacabilità, sotto tale profilo, della legge di esecuzione del Trattato"; Poland: Tryb. Konst., 24 November 2010 - K 32/09 (Lissabon), III.2.1 (EuGRZ 2012, 172): Protection of the "constitutional identity", notably "decisions specifying the fundamental principles of the Constitution and decisions concerning the rights of the individual which determine the identity of the state, including, in particular, the requirement of protection of human dignity and constitutional rights, the principle of statehood, the principle of democratic governance, the principle of a state ruled by law, the principle of social justice, the principle of subsidiarity, as well as the requirement of ensuring better implementation of constitutional values and the prohibition to confer the power to amend the Constitution and the competence to determine competences"; Art. 3 a Constitution of Slovenia: "respect for human rights and fundamental freedoms, democracy and the principles of the rule of law"; Spain: Trib. Const., 13 December 2004 - DTC 1/2004 (Constitutional Treaty), II.2. : "respeto de la soberanía del Estado, de nuestras estructuras constitucionales básicas y del sistema valores y principios fundamentales consagrados en nuestra Constitución, en el que los derechos fundamentales adquieren sustantividad propia" (EuR 2005, 339); affirmed in Trib. Const., 13 February 2014 - DTC 26/2014, II.3: "Notwithstanding, the Constitutional Court also upheld that 'In the unlikely case where, in the ulterior dynamics of the legislation of the European Union, said law is considered irreconcilable with the Spanish Constitution, without the hypothetical excesses of the European legislation with regard to the European Constitution itself being remedied by the ordinary channels set forth therein, in a final instance, the conservation of the sovereignty of the Spanish people and the given supremacy of the Constitution could lead this Court to approach the problems which, in such a case, would arise. Under current circumstances, said problems are considered inexistent 
Solange jurisprudence of the BVerfG, first formulated in 1974, the primacy of EU law depends on a standard of fundamental rights protection at EU level, which must be in essence comparable to the indispensable requirements of the Basic Law. ${ }^{6}$ Hence, the BVerfG reserves the right to measure EU action against fundamental rights standards enshrined in the Basic Law. In view of the openness of the Basic Law towards European integration (cf. the preamble and the goal of European integration formulated in Art. $23 \mathrm{GG}$ ), however, the BVerfG does not exercise this control as long as such a standard is secured at EU level, notably by the ECJ. The BVerfG has acknowledged since the Solange II ruling of 22 October 1986 that this is the case. ${ }^{7}$ These boundaries on European integration developed by the BVerfG have been incorporated into the Basic Law in the context of the ratification of the Maastricht Treaty (1992) by introducing a specific article (Art. 23) dedicated to European integration. Its first paragraph reads: "With a view to establishing a united

\section{(Footnote 5 continued)}

through the corresponding consti-tutional procedures.' (DTC 1/2004, of 13 December, Ground 4)." Chap. 10 Art. 6 Constitution of Sweden: "protection for rights and freedoms in the field of cooperation to which the transfer relates corresponds to that afforded under this Instrument of Government and the European Convention for the Protection of Human Rights and Fundamental Freedoms"; UK: High Court, 18 February 2002 (Thoburn/Sunderland City Council et a.1), [2002] EWHC 195 Admin, Nr. 69 (Lord Justice Laws): "In the event, which no doubt would never happen in the real world, that a European measure was seen to be repugnant to a fundamental or constitutional right guaranteed by the law of England, a question would arise whether the general words of the [European Communities Act] were sufficient to incorporate the measure and give it overriding effect in domestic law"; Supreme Court, 22 January 2014, [2014] UKSC 3 - HS2, para 111 (Lord Reed): "There is in addition much to be said for the view, advanced by the German Federal Constitutional Court ... that as part of a co-operative relationship, a decision of the Court of Justice should not be read by a national court in a way that places in question the identity of the national constitutional order", para 207 (Lord Neuberger and Lord Mance): "It is, putting the point at its lowest, certainly arguable (and it is for United Kingdom law and courts to determine) that there may be fundamental principles, whether contained in other constitutional instruments or recognised at common law, of which Parliament when it enacted the European Communities Act 1972 did not either contemplate or authorise the abrogation"; further the overview in BVerfG, Order of 15 December 2015 - 2 BvR 2735/14, para 47, and the contributions in: von Bogdandy et al. (2008), $\S \S 14-26$. From a comparative perspective: Huber (2008b), paras 29 ff., 65 ff., 91; Grabenwarter (2009), p. 121; Mayer and Wendel (2014), paras 13 ff.; Wendel (2011), p. 104 ff; Wollenschläger (2015b), para 23.

${ }^{6}$ BVerfG, Order of 22 October 1986 - 2 BvR 197/83, BVerfGE (reports) 73, 339, 376; further Order of 12 May 1989 - 2 BvQ 3/89, NJW 1990, 974, 974; Order of 9 July 1992 - 2 BvR 1096/92, NVwZ 1993, 883, 883; Judgment of 12 October 1993 - 2 BvR 2134/92, 2 BvR 2159/92, BVerfGE (reports) 89, 155, 174 f.; Order of 4 October 2011 - 1 BvL 3/08, BVerfGE (reports) 129, 186, 207 f. Cf. for a contextualisation of this jurisprudence, Davies (2015), p. 434.

${ }^{7}$ BVerfG, Order of 22 October 1986 - 2 BvR 197/83, BVerfGE (reports) 73, 386. The Solange I-ruling of 29 May 1974 did not yet consider the fundamental rights protection on EU level as adequate [BVerfG, Order of 29 May 1974 - 2 BvL 52/71, BVerfGE (reports) 37, 271, 285; see, however, the dissenting opinions of justice Rupp, Hirsch and Wand, ibid, $291 \mathrm{ff}]$. The Vielleicht-decision of 25.7.1979 indicated that a different assessment might be possible [BVerfG, Order of 25 July $1979-2$ BvL 6/77, BVerfGE (reports) 52, 187, 202 f.]. For restrictive tones: Kirchhof (2014), p. 1538 ff. 
Europe, the Federal Republic of Germany shall participate in the development of the European Union that is committed to democratic, social and federal principles, to the rule of law, and to the principle of subsidiarity, and that guarantees a level of protection of basic rights essentially comparable to that afforded by this Basic Law. To this end the Federation may transfer sovereign powers by a law with the consent of the Bundesrat. The establishment of the European Union, as well as changes in its treaty foundations and comparable regulations that amend or supplement this Basic Law, or make such amendments or supplements possible, shall be subject to paragraphs (2) and (3) of Article 79."8

These conditions for Germany's participation in European integration have most recently been affirmed in the ruling of the BVerfG on the European Arrest Warrant handed down on 15 December 2015. This judgment has, moreover, added in terms of fundamental rights protection limits following from Germany's constitutional identity $^{9}$ to those of the Solange jurisprudence (see on this at Sect. 2.2.2):

In general, sovereign acts of the European Union and acts of German public authority - to the extent that they are determined by Union law - are, due to the precedence of application of European Union Law (Anwendungsvorrang des Unionsrechts), ... not to be measured against the standard of the fundamental rights enshrined in the Basic Law (1.). However, the precedence of application of European Union Law is limited by the constitutional principles that are beyond the reach of European integration (integrationsfest) pursuant to Art. $23 \mathrm{sec} .1 \mathrm{sen}$ tence 3 in conjunction with Art. $79 \mathrm{sec} .3$ GG (2.). This in particular encompasses the principles contained in Art. $1 \mathrm{GG}$, including the principle of individual guilt in criminal law, which is rooted in the guarantee of human dignity (3.). It has to be ensured that, also in applying the law of the European Union or legal provisions that originate from German public authority but that are determined by Union law, these principles are guaranteed in every individual case (4.). However, one can only claim a violation of this inalienable core of fundamental rights protection before the Federal Constitutional Court if one submits in a substantiated manner that the dignity of the person is in fact interfered with (5.).

1. Pursuant to Art. 23 sec. 1 sentence 1 GG, the Federal Republic of Germany participates in establishing and developing the European Union. Uniform application of its law is of central importance for the success of the European Union ... Without ensuring uniform application and effectiveness of its law, it would not be able to continue to exist as a legal community of currently 28 Member States ... In this respect, Art. 23 sec. 1 GG also assures that Union law is effective and will be enforced ...

Therefore, through the authorisation to transfer sovereign powers to the European Unionan authorisation provided under Art. 23 sec. 1 sentence 2 GG -, the Basic Law endorses the precedence of application accorded to Union law by the Acts of Assent to the Treaties. As a rule, the precedence of application of European Union Law also applies with regard to national constitutional law ..., and, in conflict, as a rule, it results in national law being inapplicable in the specific case ...

Based on Art. $23 \mathrm{sec} .1 \mathrm{GG}$, the legislature deciding on European integration matters not only may, generally and in all matters, exempt European Union institutions and agencies from being bound by the fundamental rights and other guarantees under the Basic Law, to

\footnotetext{
${ }^{8}$ Translation available at https://www.gesetze-im-internet.de/englisch_gg/englisch_gg.html\#p0125, accessed 3 January 2017.

${ }^{9} \mathrm{Cf}$. for a critical view on the identity review only Ingold (2015), p. 1.
} 
the extent that they exercise public authority in Germany, but also German entities that execute law of the European Union ... This in particular applies to the legislature at federal and at state level if they transpose secondary or tertiary law without possessing a leeway to design (Gestaltungsspielraum) ... In contrast, the legal acts that are issued in using an existing leeway to design are amenable to scrutiny by the Federal Constitutional Court ...

2. However, the precedence of application of European Union Law only applies insofar as the Basic Law and the Act of Assent permit or provide for the transfer of sovereign powers ... The national order giving effect to Union law at national level (Rechtsanwendungsbefehl), contained in the Act of Assent, may only be given within the framework of the applicable constitutional order ... Limits to opening German statehoodlimits that apply beyond the specific design of the European integration agenda laid down in the Act of Assent-follow from the Basic Law's constitutional identity as stipulated in Art. 79 sec. 3 GG (a). This is compatible with the principle of sincere cooperation (Art. 4 sec. 3 TEU) (b) and is corroborated by the fact that the constitutional law of most Member States of the European Union contains similar limits (c).

(a) The scope of precedence of application of European Union Law is mainly limited by the Basic Law's constitutional identity that, according to Art. 23 sec. 1 sentence 3 in conjunction with Art. 79 sec. $3 \mathrm{GG}$, is beyond the reach of both constitutional amendment and European integration (verfassungsänderungs- und integrationsfest) (aa). The constitutional identity is safeguarded by the identity review conducted by the Federal Constitutional Court. (bb).

(b) To the extent that acts of an institution or an agency of the European Union have an effect that affects the constitutional identity protected by Art. $79 \mathrm{sec} .3 \mathrm{GG}$ in conjunction with the principles laid down in Arts. 1 and 20 GG, they transgress the limits of open statehood set by the Basic Law. Such an act cannot be based on an authorisation under primary law, because the legislature deciding on European integration matters, despite acting with the majority required by Art. $23 \mathrm{sec} .1$ sentence 3 GG in conjunction with Art. 79 sec. 2 GG, cannot transfer sovereign powers to the European Union which, if exercised, would affect the constitutional identity protected by Art. $79 \mathrm{sec} .3$ GG ... Nor can it be based on initially constitutional conferrals that have supposedly evolved through a development of the law, because the institution or the agency of the European Union would thereby act ultra vires ...

(c) Within the framework of the identity review, one has to review whether the principles laid down as inalienable by Art. 79 sec. 3 GG are affected by an act of the European Union ... The result of such a review may be that in exceptional cases - as is the case with the "Solange" reservation ("as long as" reservation) ... or with the ultra vires review ...-, Union law must be declared inapplicable in Germany. However, to prevent German authorities and courts from simply disregarding the Union law's claim to validity, the application of Art. $79 \mathrm{sec} .3 \mathrm{GG}$ in a manner that is open to European law in order to protect the effectiveness of the Union legal order and that takes into account the legal concept expressed in Art. $100 \mathrm{~s}$. 1 GG require that finding a violation of the constitutional identity is reserved for the Federal Constitutional Court ... This is underlined by Art. $100 \mathrm{~s}$. $2 \mathrm{GG}$ according to which in case of doubts whether a general rule of international law creates rights and duties for the individual, the court must refer the question to the Federal Constitutional Court... An identity review may also be triggered by a constitutional complaint (Art. 93 sec. 1 no. 4 a GG).... ${ }^{10}$

\footnotetext{
${ }^{10}$ BVerfG, Order of 15 December 2015 - 2 BvR 2735/14, paras 36 ff., English translation available at http://www.bundesverfassungsgericht.de/SharedDocs/Entscheidungen/EN/2015/12/ rs20151215_2bvr273514en.html, accessed 3 January 2017. See also the Lisbon-judgment of the BVerfG: BVerfG, Judgment of 30 June 2009 - 2 BvE 2/08, BVerfGE (reports) 123, 267, 335, 399, paras 191, 337 of the English translation, available at http://www.bverfg.de/e/es20090630_ 2bve000208en.html, accessed 13 January 2017.
} 


\subsubsection{Mitigation of Possible Conflicts by Substantive and Procedural Safeguards}

The application of (at least) two different fundamental rights regimes to EU acts, moreover interpreted by different institutions (the ECJ and national constitutional courts), may undoubtedly give rise to constitutional conflicts. The possibility of such conflicts is however first of all mitigated by the fact that, in the context of European integration, the Basic Law does not require an identical standard of fundamental rights protection, but only one which is comparable (cf. notably Art. 23 para. 1 sentence $1 \mathrm{GG}$ : "a level of protection of basic rights essentially comparable to that afforded by this Basic Law"). Moreover, various procedural safeguards apply. ${ }^{11}$ First of all, only the BVerfG may declare an EU act inapplicable in terms of the German legal order. ${ }^{12}$ Next, the ordinary courts must refer the case to the ECJ in order to enable the latter to assess the conformity of the EU act in question with EU law before the BVerfG may be called upon to declare the EU act inapplicable because of a violation of (national) constitutional standards. ${ }^{13}$ If a constitutional complaint (e.g. a constitutional complaint against a statute) is admissible without the prior involvement of the ordinary courts, this implies a reference to the ECJ by the BVerfG itself - a requirement which the BVerfG has mentioned, ${ }^{14}$ but it has not followed this path in the context of fundamental rights so far ${ }^{15}$ - unlike

\footnotetext{
${ }^{11}$ See for an overview, Wollenschläger (2014a), para 14.

${ }^{12}$ BVerfG, Order of 29 May 1974 - 2 BvL 52/71, BVerfGE (reports) 37, 284 f.; further Judgment of 30 June $2009-2$ BvE 2/08, BVerfGE (reports) 123, 354, para 241 of the English translation, available at http://www.bverfg.de/e/es20090630_2bve000208en.html, accessed 13 January 2017; BVerfG, Order of 15 December 2015 - 2 BvR 2735/14, para 43, English translation available at http://www.bundesverfassungsgericht.de/SharedDocs/Entscheidungen/EN/2015/12/rs20151215_ 2bvr273514en.html, accessed 3 January 2017.

${ }^{13}$ BVerfG, Order of 29 May 1974 - 2 BvL 52/71, BVerfGE (reports) 37, 271, 281; further Order of 4 October 2011 - 1 BvL 3/08, BVerfGE (reports) 129, 186, 207 f.; Seidel (2003), p. 97. See also ECJ, Joined Cases C-188/10 and C-189/10, Melki und Abdeli, [2010] ECR I-5667, paras $52 \mathrm{ff}$.

${ }^{14}$ See only BVerfG, Order of 24 January 2012 - 1 BvR 1299/05, BVerfGE (reports) 130, 151, 177 f.; Judgment of 2 March 2010 - 1 BvR 256/08, 1 BvR 263/08, 1 BvR 586/08, BVerfGE (reports) 125, 260, 307 f. See further BVerfG, Order of 15 December 2015 - 2 BvR 2735/14, para 46, English translation available at http://www.bundesverfassungsgericht.de/SharedDocs/ Entscheidungen/EN/2015/12/rs20151215_2bvr273514en.html, accessed 3 January 2017. For such an obligation: Sauer (2016), p. 1137.

${ }^{15}$ BVerfG, Order of 24 January 2012 - 1 BvR 1299/05, BVerfGE (reports) 130, 151, 191 f.; Judgment of 2 March 2010 - 1 BvR 256/08, 1 BvR 263/08, 1 BvR 586/08, BVerfGE (reports) $125,260,308$. For a critical view on not having referred cases to the ECJ so far, von Danwitz (2013), p. 261; Huber (2009), p. 582; Kingreen (2013a), p. 809 f. Reservedly: Britz (2015), p. 280 f. Beyond fundamental rights issues, the BVerfG has, for the very first time, made a reference to the ECJ in the OMT-case, see BVerfG, Judgment of 14 January $2014-2$ BvR 2728/13, 2 BvR 2729/13, 2 BvR 2730/13, 2 BvR 2731/13, 2 BvE 13/13, NJW 2014, 907; a further example is the recent reference in the case of the ECB's Expanded Asset Purchase Programme, see BVerfG, Order of 18 July 2017 - 2 BvR 859/15, 2 BvR 980/16, 2 BvR 2006/15, 2 BvR 1651/15.
} 
constitutional courts of other Member States. ${ }^{16}$ Moreover, in its recent ruling in the European Arrest Warrant case of 15 December 2015, the BVerfG applied the "acte clair" doctrine to deny the necessity of a preliminary reference to the ECJ before an EU act can be declared inapplicable:

There is no need for a preliminary ruling by the Court of Justice of the European Union under Art. 267 TFEU. The correct application of Union law is so obvious as to leave no scope for any reasonable doubt ("acte clair", cf. ECJ, Judgment of 6 October 1982, CILFIT, 283/81 [1982] ECR p. 3415, paras. 16 et seq.). In the case at hand, there is no conflict between Union law and the protection of human dignity under Art. 1 sec. 1 GG in conjunction with Art. $23 \mathrm{sec} .1$ sentence 3 in conjunction with Art. 79 sec. 3 GG. As shown above, the Framework Decision on the European arrest warrant does not require German courts and authorities to execute a European arrest warrant without reviewing its compliance with the requirements ensuing from Art. $1 \mathrm{sec} .1 \mathrm{GG}$. This is not changed by the fact that the limits of the obligation to investigate and establish the facts of the case, in particular as regards the scope of investigations permissible under Union law and the related delays in the execution of the arrest warrant, have not yet clearly been defined in the case-law of the Court of Justice of the European Union. At least in the case to be decided here, there is no indication of a conflict of Union law with the obligation of the Higher Regional Court to examine more extensively whether the complainant's rights would be safeguarded. This holds true in particular for the substantiated indications submitted by the complainant to the Higher Regional Court that under Italian [criminal] procedural law he was not afforded an opportunity to defend himself effectively. ${ }^{17}$

Furthermore, the danger of conflicts is minimised by the strict conditions for admissibility of constitutional review aiming at declaring an EU act inadmissible: The applicant has to substantiate in detail that the minimum standard of fundamental rights protection required by the Basic Law is not generally secured at EU level. ${ }^{18}$ In its judgment in the recent European Arrest Warrant case of 15 December

\footnotetext{
${ }^{16}$ See Österr. VerfGH, 28 November 2012 - G47/12 et al. (Seitlinger u.a.); Corte Cost., 13 February 2008 - 102/2008 (Tasse di Lusso Sardegna); Conseil Const., 4 April 2013 - 2013-314P QPC (M. Jeremy F.).

${ }^{17}$ BVerfG, Order of 15 December 2015 - 2 BvR 2735/14, para 125, English translation available at http://www.bundesverfassungsgericht.de/SharedDocs/Entscheidungen/EN/2015/12/rs20151215_

2 bvr273514en.html, accessed 3 January 2017. Cf. for a critical view on refraining from referring the case to the ECJ, Nowag (2016), p. 1450 f.,-identifying a new interpretation of the CILFIT-doctrine requiring a reference only in cases of conflict between national and EU law; Reinbacher and Wendel (2016), p. 342 f.; Rung (2016), p. 149 f.

${ }^{18}$ BVerfG, Order of 7 June 2000 - 2 BvL 1/97, BVerfGE (reports) 102, 147, 164; further Order of 9 January 2001 - 1 BvR 1036/99, NJW 2001, 1267, 1267 f; Order of 13 March 2007 - 1 BvF 1/05, BVerfGE (reports) 118, 79, 95; Order of 14 May 2007 - 1 BvR 2036/05, NVwZ 2007, 942, 942; Order of 14 October 2008 - 1 BvF 4/05, BVerfGE (reports) 122, 1, 20; Judgment of 30 June 2009 - 2 BvE 2/08, BVerfGE (reports) 123, 267, 334 f, paras $190 \mathrm{f}$. of the English translation, available at http://www.bverfg.de/e/es20090630_2bve000208en.html, accessed 13 January 2017.
} 
2015, the BVerfG has relativized ${ }^{19}$ this wide test by declaring - as a consequence of the protection of Germany's constitutional identity - a (possible) infringement of human dignity always subject to constitutional review (and not only if a general deficit in EU fundamental rights protection has become manifest) ${ }^{20}$ This might be a potentially wide relativisation since the identity control extends not only to the right to human dignity itself (Art. 1 para. $1 \mathrm{GG}$ ), but to the core content of other fundamental rights which is inherent in human dignity. ${ }^{21}$ A subsequent ruling of the BVerfG has however followed a restrictive path by stressing the limited extent of what might be considered the core content of fundamental rights-based requirements (such as of the right not to incriminate oneself). ${ }^{22}$ Moreover, here too a

\footnotetext{
${ }^{19}$ For the further relevance of the Solange-II-jurisprudence (beyond human dignity issues), Reinbacher and Wendel (2016), p. 334 f.
}

${ }^{20}$ BVerfG, Order of 15 December 2015 - 2 BvR 2735/14, para 34, English translation available at http://www.bundesverfassungsgericht.de/SharedDocs/Entscheidungen/EN/2015/12/rs20151215_

2bvr273514en.html, accessed 3 January 2017: "If a violation of the guarantee of human dignity is asserted, the Federal Constitutional Court reviews such a serious violation of a fundamental right in the context of the identity review...-notwithstanding its past jurisprudence declaring inadmissible both constitutional complaints and referrals in specific judicial review proceedings that assert a violation of fundamental rights under the Basic Law by secondary Community law or Union law respectively". Cf. for a critical view on this deviation, Sauer (2016), p. $1135 \mathrm{ff}$. Since the BVerfG has seen in casu no conflict between EU law and national law (in terms of fundamental rights protection), the application of the identity-control is criticised, see, Reinbacher and Wendel (2016), p. 336 f.; Rung (2016), p. 148 f.; Sauer (2016), p. 1135 f. Nuanced: Hong (2016), p. 553 ff.

${ }^{21}$ BVerfG, Judgment of 21 June 2016-BvR 2728/13, para 138 (OMT); further Order of 6 September 2016 - 2 BvR 890/16, paras 36, 39. See also Hong (2016), p. 557.

${ }^{22}$ See BVerfG, Order of 6 September 2016 - 2 BvR 890/16, para 36: "Daraus, dass der Grundsatz der Selbstbelastungsfreiheit in der Menschenwürde wurzelt, folgt allerdings nicht, dass jede verfassungsrechtlich gewährleistete Ausprägung dieses Grundsatzes auch unmittelbar dem Schutz von Art. $1 \mathrm{GG}$ unterfiele. Die Beachtung dieses Grundsatzes wird verfassungsrechtlich durch Art. 2 Abs. 1 in Verbindung mit Art. 20 Abs. 3 GG sowie Art. 2 Abs. 1 in Verbindung mit Art. 1 Abs. 1 GG sichergestellt. Nur wenn der unmittelbar zur Menschenwürde gehörende Kerngehalt der Selbstbelastungsfreiheit berührt ist, liegt auch eine Verletzung von Art. 1 GG vor. Dies wäre etwa der Fall, wenn ein Beschuldigter durch Zwangsmittel dazu angehalten würde, eine selbstbelastende Aussage zu tätigen und so die Voraussetzungen für seine strafgerichtliche Verurteilung zu schaffen. Dagegen folgt unmittelbar aus Art. 1 GG nicht, dass ein Schweigen des Beschuldigten unter keinen Umständen einer Beweiswürdigung unterzogen und gegebenenfalls zu seinem Nachteil verwendet werden darf. Dementsprechend hat das Bundesverfassungsgericht nicht beanstandet, dass in bestimmten Konstellationen des sogenannten Teilschweigens aus dem Aussageverhalten des Beschuldigten im Rahmen der Beweiswürdigung Schlüsse zu dessen Nachteil gezogen werden (vgl. BVerfGK 17, $223<227>$ ), obgleich auch in derartigen Fällen die Selbstbelastungsfreiheit berührt ist und ein gewisser Aussagedruck entstehen kann. Vor dem Hintergrund, dass die Achtung der Menschenwürde eine Würdigung und Verwertung des Schweigens zum Nachteil des Beschuldigten nicht unter allen Umständen verbietet, sind auch die Ausführungen der 3. Kammer des Zweiten Senats in ihrem Beschluss vom 22. Juni 1992 (2 BvR 1901/91, juris, Rn. 10 f.) zu verstehen, wonach eine Auslieferung von Verfassungs wegen auch dann zulässig sein kann, wenn das Schweigen des Beschuldigten im ersuchenden Staat als belastendes Indiz gewertet werden darf. Eine Auslieferung auf der Grundlage eines Europäischen Haftbefehls ist somit nicht schon dann unzulässig, wenn die Selbstbelastungsfreiheit im Prozessrecht des ersuchenden Staates nicht in demselben Umfang gewährleistet ist, wie dies von 
sufficiently substantiated application on the part of the complainant is required: "The strict requirements for activating the identity review are paralleled by stricter admissibility requirements for constitutional complaints that raise such an issue. The complainant must substantiate in detail to what extent the guarantee of human dignity that is protected by Art. $1 \mathrm{GG}$ is violated in the individual case." ${ }^{23}$ Finally, further potential conflicts are averted by interpreting (national) constitutional standards in the light of standards enshrined in EU law. ${ }^{24}$

\subsubsection{Evaluation}

In view of the high standards for declaring an EU act inapplicable in the German legal order, the Solange-Vorbehalt has been widely considered a theoretical option only. ${ }^{25}$ The practical relevance of limitations on European integration in terms of fundamental rights has however been demonstrated by the recent ruling of the BVerfG on the European Arrest Warrant of 15 December 2015 - which is already referred to as "Solange III" ruling ${ }^{26,27}$ The BVerfG held an order of Düsseldorf Higher Regional Court which declared the extradition of a person on the basis of a European Arrest Warrant permissible to be a violation of the fundamental right of human dignity (Art. 1 para. 1 GG), although this decision was determined by EU law. For, the court order related to a sentence that was rendered in absentia did not respect the principle of individual guilt, that is based on human dignity and thus belongs to the German constitutional identity (again, it should be stressed that this identity review is not identical to the Solange jurisprudence):

\section{(Footnote 22 continued)}

Verfassungs wegen im deutschen Strafverfahren der Fall ist. Vielmehr ist die Auslieferung erst dann unzulässig, wenn selbst der dem Schutz von Art. 1 GG unterfallende Kernbereich des nemo-tenetur-Grundsatzes nicht mehr gewährleistet ist."

${ }^{23}$ BVerfG, Order of 15 December 2015 - 2 BvR 2735/14, para 50, English translation available at http://www.bundesverfassungsgericht.de/SharedDocs/Entscheidungen/EN/2015/12/rs20151215_

2bvr273514en.html, accessed 3 January 2017. Emphasising the need for a restrictive application: Reinbacher and Wendel (2016), p. 335.

${ }^{24}$ BVerfG, Order of 7 July 2009 - 1 BvR 1164/07, BVerfGE (reports) 124, 199, 220, 233; further Order of 30 April 2003 - 1 PBvU 1/02, BVerfGE (reports) 107, 395, 409; Order of 4 May 2004 1 BvR 1892/03, BVerfGE (reports) 110, 339, 342; (left open in casu) Order of 26 August 2013 - 2 BvR 441/13, NJW 2013, 1540, 1542.

${ }^{25}$ See notably Dederer (2006), p. 597; Hoffmann-Riem (2002), p. 476; Huber (2008b), para 36; Kühling (2009), p. 702 f; Liisberg (2001), p. 1195; Lindner (2007b), p. 190 f; Ludwigs (2014), p. 274; Masing (2006), p. 265; idem (2016), p. 496: "reservation for extremely exceptional cases"; Rung (2016), p. 147; Szczekalla (2006), p. 1021; Voßkuhle (2010), p. 6; Walter (2004), p. 40.

${ }^{26}$ See Hong (2016), p. 550: "As long as the German Constitution remains in force, the German Federal Constitutional Court will enforce the Constitution's right to human dignity, law of the European Union notwithstanding." Reservedly: Reinbacher and Wendel (2016), p. 334.

${ }^{27}$ Qualifying this judgment as a partial overruling of Solange II: Sauer (2016), p. 1135; further Nowag (2016), p. $1447 \mathrm{ff}$. 
The challenged decision rendered by the Higher Regional Court transgresses the limits set by Art. 1 sec. 1 in conjunction with Art. 23 sec. 1 sentence 3 and Art. 79 sec. 3 GG. Executing the Framework Decision on the European arrest warrant affects the principle of individual guilt, a principle that is rooted in the guarantee of human dignity (Art. $1 \mathrm{sec} .1 \mathrm{GG}$ ) and in the principle of the rule of law (Art. $20 \mathrm{~s} .3 \mathrm{GG}$ ) and that forms part of the inalienable constitutional identity under the Basic Law (1.). This fact justifies and mandates a review of the Higher Regional Court's decision, a review according to the standards of the Basic Law, but limited to this protected interest, although the Higher Regional Court's decision is determined by Union law (2.). On the one hand, the requirements set by Union law, and by German law transposing it, on which the decision is based, comply with the requirements set by Art. $1 \mathrm{sec}$. $1 \mathrm{GG}$, as they guarantee the mandatory rights of the requested person in the context of extraditions for the purpose of executing sentences rendered in absence of the person concerned and as they do not only allow the courts that deal with the extradition to investigate appropriately, but they demand it (3.). On the other hand, however, in applying those provisions, the Higher Regional Court violated the principle of individual guilt and thereby violated the complainant's right under Art. 1 sec. $1 \mathrm{GG}$, because with regard to the interpretation of the dispositions of the Framework Decision and the Act on International Cooperation in Criminal Matters, its application of the law did not adequately take into account the significance and the scope of human dignity (4.). ${ }^{28}$

In keeping with similar reservations voiced by other constitutional courts, the Solange-Vorbehalt must not be seen as a threat to the primacy and uniform application of EU law pure and simple. Rather, it may also contribute to an improvement of fundamental rights standards at EU level by means of a judicial dialogue. $^{29}$ This has been the case for the initial Solange jurisprudence as well as for similar reservations, notably formulated by the Italian Corte Costituzionale. ${ }^{30}$ And it was also the case in the context of the European Arrest Warrant. Here, the aforementioned judgment of the BVerfG moved the ECJ to emphasise EU fundamental rights standards in this respect only a few months later. ${ }^{31}$

\subsection{Reconciling the Perspectives}

Despite the different perspectives of the ECJ, on the one hand, and of the national constitutions/national constitutional courts on the other, with regard to the relevance of national fundamental rights for European integration, tendencies towards reconciling the perspectives have become manifest.

\footnotetext{
${ }^{28}$ BVerfG, Order of 15 December 2015 - 2 BvR 2735/14, para 51, English translation available at http://www.bundesverfassungsgericht.de/SharedDocs/Entscheidungen/EN/2015/12/rs20151215_ 2bvr273514en.html, accessed 3 January 2017.

${ }^{29}$ See from a general perspective: Poli (2016), p. 373.

${ }^{30}$ Reservedly: Reinbacher and Wendel (2016), p. 343.

${ }^{31}$ ECJ, Joined Cases C-404/15 and C-659/15, Aranyosi und Căldăraru, EU:C:2016:198. See on this, Hong (2016), p. 561 ff.; Nowag (2016), p. 1452 f.; Dietz (2016), p. 1383 ff.; Reinbacher and Wendel (2016), p. $337 \mathrm{ff}$.
} 
First, the constitutional traditions common to the Member States have since the beginning constituted one source for developing EU fundamental rights (Art. 6 para. 3 TEU; Art. 52 para. 4 CFR), albeit the plurality of national traditions acts as a brake on approximation. ${ }^{32}$ Similarly, national fundamental rights are interpreted in the light of EU law standards (cf. Sect. 2.2.2).

Moreover, since Maastricht, Art. 4 para. 2 sentence 1 TEU has required the EU to respect the national identities of the Member States "inherent in their fundamental structures, political and constitutional, inclusive of regional and local self-government. ${ }^{, 33}$ Thus, EU law itself acknowledges limits to European integration in view of the national constitutional identity. It however remains a limitation of EU law, so that it is up to the ECJ to ultimately define its scope. This notwithstanding, the reference procedure enables a constructive dialogue between the latter and the courts of the Member States. ${ }^{34}$ One example is the Omega case, in which the ECJ qualified a prohibition of laser quest games - issued in view of human dignity (Art. 1 para. $1 \mathrm{GG}$ ), and thus in view of German constitutional identity-Please change to identity - as a justified restriction on the freedom to provide services. ${ }^{35}$

\section{Delimitation of National and EU Fundamental Rights with Regard to Member State Action}

While the so-called Solange-Vorbehalt (Provisional Reservation) discussed in the previous section, and first formulated in 1974, intends to secure the adequate protection of fundamental rights with respect to an action of the European Union, the perspective has taken a $180^{\circ}$ turn since the end of the 1980s. Central importance no longer attaches to the question raised in the Solange jurisprudence's with regard

\footnotetext{
${ }^{32}$ See on this Kokott and Sobotta (2010), p. 266; Wollenschläger (2010), paras $85 \mathrm{f}$. Overemphasising the relevance of national fundamental rights standards with regard to Art. 53 CFR: Hwang (2014), p. 411 ff.; idem (2016), p. 369.

${ }^{33}$ See on this clause: von Bogdandy and Schill (2010), p. $711 \mathrm{ff}$; Lerche (1996), p. 919; Pernice (2011), p. 185; Wendel (2011), p. 572 ff. The BVerfG has, in its Lisbon judgment, parallelised Art. 79 para 3 GG with Art. 4 para 2 sentence 1 TEU [cf. BVerfG, Judgment of 30 June $2009-2$ BvE 2/08, BVerfGE (reports) 123, 267, 354, 400, paras 235, 339 of the English translation, available at http://www.bverfg.de/e/es20090630_2bve000208en.html, accessed 13 January 2017; similarly Tryb. Konst., 24 November 2010-K 32/09, III.2.1, EuGRZ 2012, 172 (Lissabon)], but, in the meantime, deviated from this qualification, see BVerfG, Order of 14 January 2014 - 2 BvR 2728/13, BVerfGE (reports) 134, 366 (386 f., para 29).

${ }^{34}$ See only, Franzius (2015a), p. 401 f.; idem (2015b), p. 150.

${ }^{35}$ ECJ, Case C-36/02, Omega, [2004] ECR I-9609. See further Case C-379/87, Groener, [1989] ECR 3967, paras 12 ff; Case C-159/90, Grogan, [1991] ECR I-4685, paras 24 ff; Case C-208/09, Sayn-Wittgenstein, [2010] ECR I-13693, para 92 - with explicit reference to Art. 4 para 2 sentence 1 TEU. See insofar also, Besselink, (2012), p. 678 ff; von Bogdandy and Schill (2010), p. 707 f; von Danwitz (2008), p. 783 ff; Mayer et al. (2008), p. 71 f, 86 f; Pernice (2011), p. 204 f; Voßkuhle (2010), p. 7; Wollenschläger (2010), paras $83 \mathrm{f}$.
} 
to the extent to which an indispensable national fundamental rights standard restricts the applicability of EU law at national level. The particularly acute issue is now in fact the question of the extent to which the EU's fundamental rights, finally codified with the 2009 Treaty of Lisbon, are also binding on the Member States. ${ }^{36}$ A somewhat broad approach taken by the ECJ contrasts here with a somewhat restrictive stance assumed by the BVerfG. It has been established in Karlsruhe's settled case-law that national fundamental rights do not apply to national measures in as far as they implement mandatory requirements of EU law. The EU's fundamental rights come into effect in this regard (see Sect. 2.2). However, the expansive tendencies that are evident especially in the Fransson judgment of the ECJ of 26 February $2013^{37}$ were countered by the BVerfG a mere 2 months later in its judgment of 24 April 2013 regarding the anti-terror database, with the words "thus far and no further". Karlsruhe not only considered the expansive applicability of EU fundamental rights to the Member States to constitute an ultra vires act, but also established a new barrier to European integration assigned to the inviolable identity of the German constitutional order (Art. 79 para. $3 \mathrm{GG}$ ) - namely that a substantial scope for national fundamental rights protection has to be preserved. ${ }^{38}$

Given the issues at stake here, this is understandable. ${ }^{39}$ Experience in federal systems (for example, in the German federal state or in the USA) demonstrates that a considerable potential for unitarisation resides within central catalogues of fundamental rights - also in areas for which there are no, or only weak, competences at the federal level -, in particular if interpreted in activist jurisprudence; this is accompanied by a marginalization of the Member States' fundamental rights as well as of the (state) constitutional courts entrusted with their protection. ${ }^{40}$ This is problematical, and especially so with regard to well-functioning, differentiated systems of protection such as the protection of fundamental rights in Germany. On the other hand, federal experience also demonstrates that legal unity and precedence of federal law require uniform fundamental rights standards.

It is against this background that this article raises the question of the scope of application of EU fundamental rights to the Member States. I will be focussing primarily on the substantive delimitation of the spheres of fundamental rights, which will comprise the first two parts of this section (Sects. 3.1 and 3.2). In the third part (Sect. 3.3), I will be looking briefly at the institutional and procedural dimensions.

\footnotetext{
${ }^{36}$ On this, see Wollenschläger (2014a), paras $10 \mathrm{ff}$. Snell (2015), p. 295, speaks of "a certain irony" inherent in this development. This section updates Wollenschläger (2015a).

${ }^{37}$ ECJ, Case C-617/10, Fransson, EU:C:2013:105, paras $17 \mathrm{ff}$.

${ }^{38}$ BVerfG, Judgment of 24 April 2013 - 1 BvR 1215/07, BVerfGE (reports) 133, 277, 316; English translation available at http://www.bverfg.de/e/rs20130424_1bvr121507en.html, accessed 13 January 2017.

${ }^{39}$ On this and the following, see Eeckhout (2002), p. 945; Groussot et al. (2013), p. 100 f.; Huber (2008a), p. 190, 198 f.; idem (2011), p. 2385 f.; Kirchhof (2011), p. 3681 f.; Mayer (2009), p. 93; Wollenschläger (2014a), paras 16, $29 \mathrm{ff}$.

${ }^{40}$ Cf. already Ipsen (1968), p. 125; further Masing (2016), p. 509 ff.; Snell (2015), p. 286 f.
} 
According to the jurisprudence of the ECJ established since the end of the 1980s, Member States are bound by EU fundamental rights if national authorities act "within the scope of application of EU law". ${ }^{41}$ Art. 51 para. 1 sentence 1 CFR is somewhat more reserved in its formulation, and orders an obligation incumbent on Member States to apply EU fundamental rights "only when they are implementing Union law". Three cases may be distinguished. ${ }^{42}$ First, the implementation and enforcement of EU law, notably of EU directives and EU regulations. Second, action by Member States in a context that is determined by EU law in some manner, a category still lacking in profile and to which the aforementioned Fransson case belongs. Third, Member State action in the context of restricting the EU's fundamental freedoms, a category which was fiercely called into question shortly after the Charter came into force. This article will not deal with the third category. In my view, however, the dimension of EU fundamental rights in this constellation is exaggerated, since there is no doubt that EU law determines autonomously the admissibility and extent of limitations to the fundamental freedoms - the only issue to be avoided is to comprehensively apply EU fundamental rights on the occasion of a restriction on fundamental freedoms. ${ }^{43}$

\subsection{The Implementation and Enforcement of EU Secondary Law}

An obligation to apply EU fundamental rights exists under Art. 51 para. 1 sentence 1 CFR when Member States implement EU law, particularly including the enforcement of an EU regulation or the implementation of an EU directive. What is disputed, however, is the extent of the obligation. Do Member States only have an obligation to respect EU fundamental rights when they implement obligatory requirements of EU law, or do they also have to do so when they are granted discretionary power? Both cases also raise the question of the parallel applicability of national fundamental rights beyond EU fundamental rights. ${ }^{44}$

When implementing mandatory requirements of Union law, the Member States are not only bound by EU fundamental rights. Rather, securing the precedence and uniform application of EU law precludes the parallel application of national fundamental rights, even though national implementation acts do exist. This has been

\footnotetext{
${ }^{41}$ ECJ, Joined Cases 60/84 and 61/84, Cinéthèque, [1995] ECR 2605, para 26 ("area”); Case C-260/89, ERT, [1991] ECR I-2925, para 42; Case C-368/95, Familiapress, [1997] ECR I-3689, para 24; Case C-276/01, Steffensen, [2003] ECR I-3735, para 70.

${ }^{42}$ See, Wollenschläger (2014a), paras $16 \mathrm{ff}$.

${ }^{43}$ Cf. the so-called ERT-jurisprudence (ECJ, Case C-260/89, ERT, [1991] ECR I-2925, paras 42 ff.); also confirmed after the CFR has entered into force in ECJ, Case C-390/12, Pfleger, EU: C:2014:281, paras $30 \mathrm{ff}$. Cf. for a detailed discussion, Wollenschläger (2014a), paras $25 \mathrm{ff}$.; idem (2014b), p. 577. Reservedly: Snell (2015), p. 304 ff.

${ }^{44} \mathrm{Cf}$. for more details and with further references, Wollenschläger (2014a), paras $18 \mathrm{ff}$.
} 
recognized-within the limits of the Solange jurisprudence and constitutional identity (see Sect. 2.2) - by the BVerfG, and convincingly so. ${ }^{45}$ Let us take the example of EU Directive 2006/24/EU on data retention (which has since been held void because it infringes EU fundamental rights ${ }^{46}$ ). Here, national legislation implements the obligation incumbent on telecommunications providers to retain connection data as stipulated by EU secondary law. If we were to examine these national implementation acts in the light of national fundamental rights, the retention of data made obligatory by EU law would depend on the result of the national scrutiny of fundamental rights in the respective Member States. This conflicts with the precedence and uniform application of EU law and-at least as long as there is an adequate standard of protection at EU level-is also not imperative in the interest of protecting fundamental rights. Besides, given that they have no leeway of their own, the Member States function as an extended arm of the EU, so that, from a substantive point of view, there can be no question of their exercising national sovereign power. ${ }^{47}$

The situation is different in cases where EU law grants discretion to Member States with regard to implementation-in our example, Member States may determine how long telecommunications providers have to retain data on telecommunications connections for periods ranging between 6 and 24 months. Nevertheless, the ECJ assumes that Member States are also obliged to adhere to EU fundamental rights in the case of discretion. This is because such discretion has been granted by EU law. ${ }^{48}$ This approach is not

\footnotetext{
${ }^{45}$ BVerfG, Order of 13 March 2007 - 1 BvF 1/05, BVerfGE (reports) 118, 79, 95 ff. Affirmative: Britz (2015), p. 276. Cf. for a critical view with regard to the criterion of determinedness, Sauer (2016), p. 1135 f.; further, Franzius (2015b), p. 148 ff., 152. In view of the primacy of EU law, it is admissible to scrutinise the national measures with regard to national fundamental rights and confirm it (only a declaration as unconstitutional would be problematic), cf. only BVerfG, Order of 02 March 2010-BVerfGE (reports) 125, 260, 309, para 187 of the English translation, available at http://www.bverfg.de/e/rs20100302_1bvr025608en.html, accessed 13 January 2017: "With these contents, the Directive can be implemented in German law without violating the fundamental rights of the Basic Law. The Basic Law does not prohibit such storage in all circumstances. On the contrary, even independent of any priority of Community law, it may permissibly be ordered in compliance with the fundamental rights enshrined in the Basic Law (see IV below). A review of the challenged provisions as a whole by the yardstick of German fundamental rights is therefore not in conflict with Directive 2006/24/EC, and therefore the validity and priority of the latter is not relevant.”; Bäcker (2015), p. 409 f.; Britz (2015), p. 277.

${ }^{46}$ ECJ, Joined Cases C-293/12 and C-594/12, Digital Rights Ireland Ltd et al., EU:C:2014:238.

${ }^{47}$ Cf. ECJ, Case C-206/13, Siragusa, EU:C:2014:126, para 32; von Danwitz (2013), p. 259; Dederer (2006), p. 584; Jacobs (2001), p. 333 f.; Masing (2016), p. 499 f.; Snell (2015), p. 301 f.; Weiler and Fries (1999), p. $161 \mathrm{f}$.

${ }^{48}$ Cf. ECJ, Case C-540/03, Parliament/Council, [2006] ECR I-5769, paras 104 f.; further Joined Cases C-411/10 and C-493/10, N.S. et al., [2011] ECR I-13905, paras 64 ff.; Case C-418/11, Texdata, EU:C:2013:588, paras $70 \mathrm{ff} .:$ "In the present case, the main proceedings concern the penalty imposed for failure to comply with the disclosure obligation, as laid down in the Eleventh Directive. As can be seen from paragraph 49 above, the EU legislature, by Article 12 of the Eleventh Directive, left the Member States responsible for determining the appropriate penaltiesthat is to say, penalties which are effective, proportionate and dissuasive - in order to ensure
} 
uncontroversial. ${ }^{49}$ At first sight, there appear to be good reasons for this restrictive position. ${ }^{50}$ True, an obligation incumbent on the Member States with regard to EU fundamental rights, also when enjoying discretion, is still covered by the wording of Art. 51 para. 1 sentence 1 CFR, referring to "implementing". However, the addition of the word "only", and the fact that it contains reservations regarding Member States' competences [cf. only Art. 51 para. 2 CFR; cf. further Art. 6 para. 1 subpara. 2 TEU], means that EU law expresses a somewhat restrictive tendency. Moreover, the unitarisation effect resulting from an obligation with regard to EU fundamental rights questions the granting of discretion to the Member States. Finally, if EU law opens up various options to the Member States, then choosing one of these options does not endanger the uniform application of EU law.

However convincing this delimitation of the spheres of fundamental rights may seem at first, we must not overlook its problems and limitations. ${ }^{51}$ For, differentiating between obligatory requirements of a directive and those that grant discretion may artificially split up a uniform set of circumstances and its regulatory context, which can give rise not only to legal difficulties, but also to deficits in terms of protection, since protection of fundamental rights is then parcelled out. Having said that, the following objection is even more important, and it significantly reduces the persuasiveness of the separation solution: Not every leeway is a leeway. For,

\section{(Footnote 48 continued)}

compliance with the disclosure obligation [para. 49: Under Article 12 of the Eleventh Directive, Member States are to provide for appropriate penalties in the event of failure to disclose accounting documents. However, that directive does not lay down more precise rules with regard to the establishment of those national penalties and, in particular, it does not establish any explicit criterion for the assessment of the proportionality of such penalties.]"; Bäcker (2015), p. $402 \mathrm{ff}$;; von Bogdandy et al. (2012), p. 55; von Danwitz (2009), p. 27 ff.; Epiney (2007), p. 63 f.; Franzius (2015b), p. 141; Griebel (2013), p. 388; Ladenburger (2012), p. 165; Lenaerts (2015), p. 354 f.; Trstenjak and Beysen (2013), p. 304 ff.; Ward (2014), para 51.119.

${ }^{49}$ Disagreeing: ECJ, Case C-2/92, Bostock, [1993] ECR I-972, Opinion of AG Gulmann, paras 33 f.; Calliess (2009), p. 120 f.; Masing (2006), p. 267; further Kingreen (2016), paras 14 f.; idem (2013b), p. 453. The position of the BVerfG is not entirely clear since most rulings only address the issue of the applicability of national fundamental rights in this situation. A rejection of the applicability of EU fundamental rights might be seen in BVerfG, Judgment of 24 April 2013 - 1 BvR 1215/07, BVerfGE (reports) 133, 277, 313 f.; English translation available at http://www. bverfg.de/e/rs20130424_1bvr121507en.html, accessed 13 January 2017: “The European fundamental rights under the EUCFR are not applicable in the case at hand. The challenged provisions must be measured against the fundamental rights under the Basic Law, if only because they are not governed by Union law ... Accordingly, this is also not a case of implementation of European Union law, which alone could result in the Member States' being bound by the Charter of Fundamental Rights (Art. $51 \mathrm{sec} .1$ sentence 1 EUCFR)." This finding is subsequently relativised, though [see ibid., p. 316 and on this Thym (2013), p. 894 f.].

${ }^{50}$ See ECJ, Case C-2/92, Bostock, [1993] ECR I-972, Opinion of AG Gulmann, paras $33 \mathrm{f}$; Calliess (2009), p.120; Kingreen (2013b), p. 453; Lindner (2007b), p. 191 f.; Masing (2006), p. 267.

${ }^{51}$ Cf. Calliess (2009), p. 121; von Danwitz (2009), p. 23, 27 f.; De Cecco (2006), p. 11; Di Fabio (2006), p. 10 f., 15; Franzius (2015a), p. 391 f.; idem (2015b), p. 141; Lindner (2007a), p. 72; Reinbacher and Wendel (2016), p. 336; Thym (2013), p. 892. 
requirements of EU law might reduce the scope of discretion, where that latter seems to be granted according to the wording of a directive. This is because directives - given that they are acts of the Union legislature - have to be interpreted in line with requirements of EU fundamental rights. In our example, therefore, the question would arise as to whether the data retention period of between 6 and 24 months provided for in the directive is consistent with EU fundamental rights. Were we to conclude that, in view of the considerable limitation of fundamental rights, a maximum of 6 months' retention is permitted at most, there would be no leeway at national level at all. Hence, as a preliminary question for applying national fundamental rights to national acts exercising discretion granted by EU law, the question always arises as to whether and to what extent this leeway is limited by EU law. A strict separation of spheres of fundamental rights is therefore not possible in view of the layered process of law-making. ${ }^{52}$

Against this background, we have to consider the applicability of national fundamental rights to acts of Member States that make use of discretionary powers. As the ECJ has emphasized several times recently, national fundamental rights may be applied, but only "provided that ... neither the level of protection of the Charter ... nor the priority, the unity and the effectiveness of EU law is affected". 53 The BVerfG applies national fundamental rights, but sometimes assumes a very broad scope of discretion with regard to implementation (and does so without referring to the ECJ). ${ }^{54}$

\footnotetext{
${ }^{52} \mathrm{Cf}$. on the interaction, ECJ, Joined Cases C-293/12 and C-594/12, Digital Rights Ireland Ltd et al., EU:C:2014:238, paras 60 ff.; further Ohler (2013), p. 1437.

${ }^{53}$ Cf. ECJ, Case C-399/11, Melloni, EU:C:2013:107, para 60; further Case C-617/10, Fransson, EU:C:2013:105, para 29; Opinion 2/13, EU:C:2014:2454, paras $187 \mathrm{f}$. (accession to the ECHR); Case C-168/13, Jeremy F., ECLI:EU:C:2013:358, para 53; Wollenschläger (2014a), para 24, with further references. See further-distinguishing three types of (EU) legislative consensus with regard to remaining discretion of the Member States-Lenaerts (2015), p. $357 \mathrm{ff}$. See for a solution for preserving national autonomy by granting a margin of appreciation to the Member States only Bäcker (2015), p. 406 f.,- - this approach is, however, questionable since it leads to double standards vis-à-vis the Member States and the EU and neglects that the task of the ECJ is not to guarantee a minimum fundamental rights standard within the EU (like the EctHR), but to provide full fundamental rights protection within the scope of applicability of EU law, cf. Wollenschläger (2014a), para 77, with further references. Reservedly: Franzius (2015b), p. 141 ff. For a restrictive approach questioning the primacy of EU (fundamental rights) law: Kirchhof (2014), p. $1538 \mathrm{ff}$. Proposing a reversed Solange-formula, i.e. an application of national fundamental rights as long as they guarantee adequate protection, Ludwigs (2014), p. 282.

${ }^{54}$ See only BVerfG, Order of 02 March 2010 - BVerfGE (reports) 125, 260, 308 f., English translation available at http://www.bverfg.de/e/rs20100302_1bvr025608en.html, accessed 13 January 2017; Order of 19 July 2011 - 1 BvR 1916/09, BVerfGE (reports) 129, 78, 104 f.; Order of 24 January 2011 - 1 BvR 1299/05, BVerfGE (reports) 130, 151, $186 \mathrm{ff}$. Cf. for a critical view Griebel (2013), p. 386 ff., 395. Cf. further BVerfG, Order of 15 December 2015 - 2 BvR 2735/14, English translation available at http://www.bundesverfassungsgericht.de/SharedDocs/ Entscheidungen/EN/2015/12/rs20151215_2bvr273514en.html, accessed 13 January 2017, and on this Hong (2016), p. $553 \mathrm{ff}$.
} 


\subsection{Member States' Acting in a Context Determined by EU Law}

The question of whether Member States implement EU law, and are therefore bound by EU fundamental rights, does not only arise with regard to obligations that are clearly defined by EU law, such as the previously discussed requirement contained in an EU directive that data from telecommunication connections be retained for a certain period of time. This takes us to the second part of this section-namely to the diffuse group of cases in which Member States act in a context that is somehow determined by EU law. The debate on this issue is only in its very infancy. ${ }^{55}$

One prominent example is the Fransson case, which has already been mentioned several times. This case concerns the applicability of the EU fundamental right of "ne bis in idem" (Art. $50 \mathrm{CFR}$ ) with regard to national tax and criminal proceedings that run in parallel and which were based on infringements of the obligation to declare Value Added Tax. The fact that neither national criminal procedural law nor the law on tax sanctions implement specific norms of EU secondary law has been declared immaterial by the ECJ. According to the Court, it is, rather, sufficient for the levying of VAT and for the sanctioning of violations of the obligation to declare taxes to be determined by EU law. In order to establish such a determination, the ECJ has referred to the principle of loyalty, the obligation to declare taxes provided for by EU secondary law, and the obligation incumbent on primary law "to impose effective penalties for conduct prejudicial to the financial interests of the European Union" (Art. 325 TFEU). ${ }^{56}$ That said, are these links to EU law sufficient to activate EU fundamental rights? One might even go further and concur with Advocate General Sharpston in applying EU fundamental rights in all areas of shared competences irrespective of their having been exercised by passing EU legislation. This would result in a far-reaching obligation of the Member States to apply EU fundamental rights. ${ }^{57}$

Generally speaking, the ECJ still has no clear line here. ${ }^{58}$ Besides far-reaching judgments such as the Fransson case just mentioned, there are also restrictive approaches - for example, the repudiation of an obligation with regard to fundamental rights where EU competences have not been exercised (Bartsch case), ${ }^{59}$ or

\footnotetext{
${ }^{55}$ For more details, see Wollenschläger (2014a), paras $29 \mathrm{ff}$., with further references.

${ }^{56}$ ECJ, Case C-617/10, Fransson, EU:C:2013:105, paras 17 ff. Approving: Franzius (2015b), p. 141; Kokott and Sobotta (2015), p. 70 f. Disagreeing: Britz (2015), p. 278.

${ }^{57}$ ECJ, Case C-34/09, Ruiz Zambrano, [2011] ECR I-1177, opinion of AG Sharpston, paras $163 \mathrm{ff}$.

${ }^{58}$ See for an overview of the case-law: Snell (2015), p. $292 \mathrm{ff}$.

${ }^{59}$ ECJ, Case C-427/06, Bartsch, [2008] ECR I-7245, para 18.
} 
where there is only an indirect link to EU policy areas (Annibaldi case). ${ }^{60,61}$ The BVerfG emphasized in its judgment on the anti-terror database that an indirect link to EU law is not sufficient to apply EU fundamental rights, and even created a new barrier to European integration consisting in the preservation of a meaningful fundamental rights protection scheme at national level. ${ }^{62}$ The English press release reads as follows:

The constitutional complaint provides no reasons for a preliminary ruling before the European Court of Justice. Clearly, the Counter-Terrorism Database Act and actions that are based on it do not constitute an implementation of Union law according to Art. $51 \mathrm{sec} .1$ sentence 1 of the Charter of Fundamental Rights of the European Union. The Counter-Terrorism Database Act pursues nationally determined objectives which can affect the functioning of the legal relationships under EU law merely indirectly. Thus, the European fundamental rights are from the outset not applicable, and the European Court of Justice is not the lawful judge according to Art. $101 \mathrm{sec} .1$ sentence 2 of the Basic Law ... The European Court of Justice's decision in the case Åkerberg Fransson ... does not change this conclusion. As part of a cooperative relationship, this decision must not be read in a way that would view it as an apparent ultra vires act or as if it endangered the

\footnotetext{
${ }^{60}$ ECJ, Case C-309/96, Annibaldi, [1997] ECR I-7493, paras 13 ff.; further Case C-40/11, Iida, ECLI:EU:C:2012:691, para 79: "To determine whether the German authorities' refusal to grant Mr. Iida a 'residence card of a family member of a Union citizen' falls within the implementation of European Union law within the meaning of Article 51 of the Charter, it must be ascertained among other things whether the national legislation at issue is intended to implement a provision of European Union law, what the character of that legislation is, and whether it pursues objectives other than those covered by European Union law, even if it is capable of indirectly affecting that law, and also whether there are specific rules of European Union law on the matter or capable of affecting it (see Case C 309/96 Annibaldi [1997] ECR I 7493, paragraphs 21 to 23)."

${ }^{61}$ Cf. further ECJ, Case C-457/09, Chartry, [2011] ECR I-819, paras 23 ff. (intermediate proceedings); Case C-466/11 Gennaro Currà and Others, EU:C:2012:465, para 25 (compensation in the context of Second World War); Case C-369/12, Corpul Naţional al Polițiștilor, EU: C:2012:725, para 15 (salary reductions in the public sector); Case C-370/12, Pringle, EU: C:2012:756, paras 179 f. (ESM-Treaty); Case C-128/12, Sindicato dos Bancários, EU:C:2013:149, paras $11 \mathrm{ff}$. (salary reductions in the public sector); Case C-73/13, T., EU:C:2013:299, paras $11 \mathrm{ff}$. (attorneys' fees); Case C-282/14, Stylinart, EU:C:2014:2486, paras 18 and 20 (expropriation): "à cet égard, la Cour a itérativement refusé de reconnaître sa compétence dans une situation où la décision de renvoi ne contient aucun élément concret permettant de considérer que l'objet de la procédure au principal concerne l'interprétation ou l'application d'une règle de l'Union autre que celles figurant dans la Charte ... à cet égard, la question posée par la juridiction de renvoi se borne à citer des dispositions de la Charte sans invoquer d'autres dispositions du droit de l'Union. Certes, selon la description faite par la juridiction de renvoi, l'activité économique de la requérante au principal consiste à assurer des transports internationaux et la livraison de meubles à destination de magasins de meubles situés en Allemagne. Toutefois, la demande de décision préjudicielle ne contient aucun élément concret qui aurait conduit celle-ci à s'interroger sur l'interprétation ou l'application d'une règle de l'Union autre que celles figurant dans la Charte"; Case C-199/14, Kárász, EU:C:2014:2243, paras 14 ff. (national pension); Case C-305/14, Băbăşan, EU:C:2015:97, paras 13 ff. (electoral law); Case C-451/14, Petrus, EU:C:2015:71, paras 16 ff. (prescription acquisitive). Cf. further, von Danwitz (2013), p. 260; Iglesias Sánchez (2012), p. 1588 ff.

${ }^{62}$ BVerfG, Judgment of 24 April 2013 - 1 BvR 1215/07, BVerfGE (reports) 133, 277, 316; English translation available at http://www.bverfg.de/e/rs20130424_1bvr121507en.html, accessed 13 January 2017. See also Wollenschläger (2015b), para 103.
} 
protection and enforcement of the fundamental rights in the member states in a way that questioned the identity of the Basic Law's constitutional order. The Senate acts on the assumption that the statements in the ECJ's decision are based on the distinctive features of the law on value-added tax, and express no general view. The Senate's decision on this issue was unanimous. ${ }^{63}$

Where then can we draw the line? ${ }^{64}$ For the reasons explained in the context of an obligation with respect to fundamental rights when Member States enjoy discretion, a restrictive reading seems appropriate. ${ }^{65}$ Only sufficiently specific requirements of (primary and secondary) EU law trigger the applicability of EU fundamental rights. ${ }^{66}$ This requires a careful analysis of the EU legislation in question. In view of the variety of possible constellations, a great deal of concretization work still needs to be carried out in the jurisdictional and academic fields in order to operationalize this delimitation. ${ }^{67}$ In any case, competences that have not yet been exercised certainly do not suffice. ${ }^{68}$

The ECJ has also recently adopted a more restrictive approach-namely, in its judgment in the Siragusa case of 6 March 2014, the subject of which was the question of the applicability of EU fundamental rights to an order issued by an authority of one of the Member States to remove buildings that had been erected in breach of landscape protection law. ${ }^{69}$ No specific rules of EU law applied to this situation; the referring Italian court, however, saw a link to EU environmental policy, albeit the latter was not sufficient for the ECJ. Although it reaffirmed its interpretation as developed in the Fransson case of Art. 51 para. 1 sentence 1 CFR, according to which EU fundamental rights apply to any national measure falling within the scope of application of EU law, ${ }^{70}$ the ECJ, though drawing on previously developed principles, also stressed the limits of the obligation of the Member States to respect EU fundamental rights. Thus, 'the concept of 'implementing Union law', as referred to in Art. 51 of the Charter, requires a certain degree of connection above and beyond the matters covered being closely related or one of those matters having an indirect impact on the other". ${ }^{71}$ The important point is whether the

\footnotetext{
${ }^{63}$ Press release available at http://www.bundesverfassungsgericht.de/SharedDocs/Pressemitteilungen/ EN/2013/bvg 13-031.html, accessed 13 January 2017.

${ }^{64}$ Too far-reaching the fusion model of Thym (2015), p. $57 \mathrm{ff}$; see further, Franzius (2015b), p. $151 \mathrm{ff}$. The challenge lies - with Masing (2015), p. 477; idem (2016), p. 502 ff.; further Britz (2015), p. 280 f.-in delimitating the different spheres of fundamental rights. Advocating an extension of the BVerfG's standard of review to the EU fundamental rights Bäcker (2015), p. 410 ff.

${ }^{65}$ See Kirchhof (2011), p. 3684 ff.; Ladenburger (2012), p.163 f.; Masing (2016), p. 506 ff. ${ }^{66}$ von Danwitz (2009), p. 28; further Kokott and Sobotta (2015), p.71 f.; Masing (2016), p. 507 f.

${ }^{67}$ For a test, cf. Ward (2014), para 51.118. See further, Britz (2015), p. 277 ff.: danger for efficient implementation of EU law decisive.

${ }^{68}$ Cf. Ohler (2013), p. 1434; Thym (2013), p. 894.

${ }^{69}$ ECJ, Case C-206/13, Siragusa, EU:C:2014:126.

${ }^{70} \mathrm{ECJ}$, Case C-206/13, Siragusa, EU:C:2014:126, paras $21 \mathrm{f}$.

${ }^{71}$ Ibid., para 24.
} 
national legislation in question "is intended to implement a provision of EU law; the nature of that legislation and whether it pursues objectives other than those covered by EU law, even if it is capable of indirectly affecting EU law; and also whether there are specific rules of EU law on the matter or capable of affecting it". ${ }^{72}$ In any case, EU law needs to impose on Member States an obligation "with regard to the situation at issue in the main proceedings". ${ }^{73}$ Finally, the critical point is whether the non-application of EU fundamental rights would "undermine the unity, primacy and effectiveness of EU law". ${ }^{74}$ The recent judgments in the Hernández case of 10 July 2014, in the Dano case of 11 November 2014, and in the Nistlahnz Poclava case of 5 February 2015, follow the same lines. ${ }^{75}$ However, the ruling on the applicability of EU fundamental rights to the retention of telecommunication data handed down on 21 December 2016 stands for a wide understanding. ${ }^{76}$

\subsection{Procedural Implications}

Let me conclude by taking a brief look at the procedural implications. Insofar as obligatory requirements of EU law are implemented, and national fundamental rights do not therefore apply, the BVerfG has no jurisdiction, as its competence is limited to applying national constitutional law. ${ }^{77}$ Matters are different where discretionary powers of Member States are concerned. Due to the parallel applicability of EU and national fundamental rights, the BVerfG retains jurisdiction in view of the latter. Even so, the question will often arise as to how far Member States' leeway is limited by EU law, which takes precedence. This presumes a reference to the ECJ, a path which the BVerfG has not followed so far in the area of fundamental rights (see Sect. 2.2.2). This presents challenges to legal protection in two respects: First, the obligation to refer a case to the ECJ not only takes time, but it may also overburden the latter in view of the great number of cases involving such issues of EU law. Second, individuals may challenge EU legislation before the ECJ only under very limited conditions [cf. Art. 263 para. 4 TFEU]. As an outlook, it should be mentioned that some commentators advocate an extension of the BVerfG's competence to review EU fundamental rights standards, be it by interpreting national fundamental rights in the light of EU fundamental rights, or by directly applying EU fundamental rights. ${ }^{78}$

\footnotetext{
${ }^{72}$ Ibid., para 25.

${ }^{73}$ Ibid., para 26. See also, Ladenburger (2012), p. 167 N. 104; Lenaerts and Gutiérrez-Fons (2014), paras $55.12 \mathrm{ff}$.

${ }^{74}$ ECJ, Case C-206/13, Siragusa, EU:C:2014:126, paras $31 \mathrm{f}$.

${ }^{75}$ ECJ, Case C-198/13, Hernández, EU:C:2014:2055, paras 32 ff. Case C-333/13, Dano, EU: C:2014:2358, paras 87 ff.; Case C-117/14, Nisttahuz Poclava, EU:C:2015:60, paras $27 \mathrm{ff}$.

${ }^{76}$ ECJ, Joined Cases C-203/15 and C-698/15, Tele2 Sverige, EU:C:2016:970. Disagreeing, Wollenschläger and Krönke (2016), p. 906.

${ }^{77}$ See also N. 46.

${ }^{78}$ See N. 65.
} 
As a last procedural implication, let me point to the strengthening of ordinary courts in relation to the BVerfG, since the former (unlike the BVerfG) have jurisdiction to apply EU fundamental rights, and thus to set aside national legislation that is in breach of them. ${ }^{79}$

\section{Conclusion}

The constitutional limitations on European integration, and more specifically on the precedence of EU law, produce an ambivalent result: On the one hand, the principles of precedence and of uniform application of EU law are endangered unilaterally. However, the contribution of these limitations to improving the protection of fundamental rights at EU level must not be overlooked, and neither must the gradual reconciliation of these two perspectives.

With regard to national law, the principles of the precedence and uniform application of EU law require EU fundamental rights to be applied to national law determined by EU law. This extends not only to constellations in which secondary EU law explicitly obliges the Member States to act in a certain way. Rather, even in cases in which Member States enjoy discretion, the question arises as to the extent to which EU fundamental rights limit the scope of discretion that is awarded. In this (limited) sense, the Fransson judgment of the ECJ was right to stress: "Since the fundamental rights guaranteed by the Charter must therefore be complied with where national legislation falls within the scope of European Union law, situations cannot exist which are covered in that way by European Union law without those fundamental rights being applicable. The applicability of European Union law entails applicability of the fundamental rights guaranteed by the Charter." 80 Or: "Metaphorically speaking, this means that the Charter is the "shadow' of EU law". ${ }^{81}$

The latter reflects the reason (not always sufficiently well considered) why Member States are increasingly bound by EU fundamental rights. This development results from a growing allocation of competences to the European Union and the exercise of these competences, notwithstanding expansive approaches in the ECJ's jurisprudence and in the literature (a safety net for fundamental rights ${ }^{82}$ ). It seems to me to be important to give this some thought - against the background, for example, of the current debate about the general regulation on data protection. ${ }^{83}$

\footnotetext{
${ }^{79}$ Cf. Bäcker (2015), p. 400 ff.; Thym (2013), p. 895; further, Kingreen (2013a), p. 808 f.

${ }^{80}$ ECJ, Case C-617/10, Fransson, EU:C:2013:105, para 21; further Case C-418/11, Texdata, EU: C:2013:588, para 73 .

${ }^{81}$ Lenaerts and Gutiérrez-Fons (2014), para 55.26.

${ }^{82}$ von Bogdandy et al. (2012), p. 45. Against: Britz (2015), p. 276.

${ }^{83}$ See also, Britz (2015), p. 281; Franzius (2015b), p. 144.
} 


\section{References}

Bäcker M (2015) Das Grundgesetz als Implementationsgarant der Unionsgrundrechte. EuR 50:389-414

Besselink LFM (2012) Case C-208/09, Ilonka Sayn-Wittgenstein v. Landeshauptmann von Wien, Judgment of the Court (Second Chamber) of 22 December 2010. CML Rev 49:671-693

Britz G (2015) Grundrechtsschutz durch das Bundesverfassungsgericht und den Europäischen Gerichtshof. EuGRZ 42:275-281

Calliess C (2009) Europäische Gesetzgebung und nationale Grundrechte-Divergenzen in der aktuellen Rechtsprechung von EuGH und BVerfG? JZ 64:113-121

Davies B (2015) Resistance to European Law and Constitutional Identity in Germany: Herbert Kraus and Solange in its intellectual context. Eur Law J 21:434-459

de Cecco F (2006) Room to move? Minimum harmonization and fundamental rights. CML Rev 43:9-30

Dederer H-G (2006) Die Architektonik des europäischen Grundrechtsraums. ZaöRV 66:575-624

Di Fabio U (2006) Grundfragen der Europäischen Grundrechtsordnung. In: Löwer W (ed) Bonner Gespräche zum Energierecht, vol 1. V\&R unipress, Göttingen, pp 9-20

Dietz S (2016) Die Menschenwürde im Diskurs zwischen BVerfG und EuGH. Fundament für einen effektiven Individualschutz in einem konfliktfreien Unionsgerichtsverbund. NVwZ $35: 1383-1385$

Eeckhout P (2002) The EU charter of fundamental rights and the federal question. CML Rev 39:945-994

Epiney A (2007) Zur Reichweite der Grundrechtsbindung des Gemeinschaftsgesetzgebers. ZAR 27:61-64

Franzius C (2015a) Grundrechtsschutz in Europa. Zwischen Selbstbehauptungen und Selbstbeschränkungen der Rechtsordnungen und ihrer Gerichte. ZaöRV 75:383-412

Franzius C (2015b) Strategien der Grundrechtsoptimierung in Europa. EuGRZ 42:139-153

Grabenwarter C (2009) Staatliches Unionsverfassungsrecht. In: von Bogdandy A, Bast J (eds) Europäisches Verfassungsrecht. Theoretische und dogmatische Grundzüge. Springer, Berlin, pp 121-175

Griebel J (2013) Doppelstandards des Bundesverfassungsgerichts beim Schutz europäischer Grundrechte. Der Staat 52:371-399

Groussot X, Pech L, Petursson GT (2013) The reach of fundamental rights on member state action after Lisbon. In: de Vries SA, Bernitz U, Weatherill S (eds) The protection of fundamental rights in the EU after Lisbon. Hart, Oxford, pp 97-118

Hoffmann-Riem W (2002) Kohärenz europäischer und nationaler Grundrechte. EuGRZ 29: $473-483$

Hong M (2016) Human Dignity, Identity Review of the European Arrest Warrant and the Court of Justice as a Listener in the Dialogue of Courts: Solange-III and Aranyosi: BVerfG 15 December 2015, 2 BvR 2735/14, Solange III, and ECJ (Grand Chamber) 5 April 2016, Joined Cases C-404/15 and C-659/15 PPU, Aranyosi and Caldararu. Eur Const Law Rev 12:549-563

Huber PM (2008a) Unitarisierung durch Gemeinschaftsgrundrechte-Zur Überprüfungsbedürftigkeit der ERT-Rechtsprechung. EuR 43:190-199

Huber PM (2008b) Vergleich. In: von Bogdandy A, Cruz Villalón P, Huber PM (eds) Handbuch Ius Publicum Europaeum. Offene Staatlichkeit-Wissenschaft vom Verfassungsrecht, vol. 2. C.F. Müller, Heidelberg, § 26

Huber PM (2009) Das europäisierte Grundgesetz. DVB1 124:574-582

Huber PM (2011) Auslegung und Anwendung der Charta der Grundrechte. NJW 64:2385-2390

Hwang S-P (2014) Grundrechte unter Integrationsvorbehalt? Eine rahmenorientierte Überlegung zur Debatte um die Bindung der Mitgliedstaaten an die Unionsgrundrechte. Europarecht 49:400-419 
Hwang S-P (2016) Grundrechtsoptimierung unter dem Vorbehalt des unionsrechtlichen Vorrangs? -Zur Auslegung des Art. $53 \mathrm{GRCh}$ im Lichte des Vorrangs des Unionsrechts. ZEuS 29:369-388

Iglesias Sánchez S (2012) The court and the charter: the impact of the entry into force of the Lisbon Treaty on the ECJ's approach to fundamental rights. CML Rev 49:1565-1612

Ingold A (2015) Die verfassungsrechtliche Identität der Bundesrepublik Deutschland. KarriereKonzept-Kritik. AöR 140:1-30

Ipsen HP (1968) Gleichheit. In: Neumann FL, Nipperdey HC, Scheuner U (eds) Die Grundrechte, vol 2, 2nd edn. Duncker \& Humblodt, Berlin, pp 111-198

Jacobs FG (2001) Human rights in the European Union: the role of the Court of Justice. Eur Law Rev 26:331-341

Kingreen T (2013a) Die Grundrechte des Grundgesetzes im europäischen Grundrechtsföderalismus. J Zeit 68:801-811

Kingreen T (2013b) Ne bis in idem: Zum Gerichtswettbewerb um die Deutungshoheit über die Grundrechte. EuR 48:446-453

Kingreen T (2016) Art. 51 GRC. In: Calliess C, Ruffert M (eds) EUV/AEUV. Das Verfassungsrecht der Europäischen Union mit Europäischer Grundrechtecharta. Kommentar. C. H. Beck, München, pp 2949-2964

Kirchhof F (2011) Grundrechtsschutz durch europäische und nationale Gerichte. NJW 64:36813686

Kirchhof F (2014) Nationale Grundrechte und Unionsgrundrechte. Die Wiederkehr der Frage eines Anwendungsvorrangs unter anderer Perspektive. NVwZ 33:1537-1541

Kokott J, Sobotta C (2010) Die Charta der Grundrechte der Europäischen Union nach Inkrafttreten des Vertrags von Lissabon. EuGRZ 37:265-271

Kokott J, Sobotta C (2015) Protection of fundamental rights in the European Union: on the relationship between EU fundamental rights, the European Convention and National Standards of Protection. Yearb Eur Law 34:60-73

Kühling J (2009) Grundrechte. In: von Bogdandy A, Bast J (eds) Europäisches Verfassungsrecht. Theoretische und dogmatische Grundzüge. Springer, Berlin, pp 657-704

Ladenburger C (2012) EU Institutional Report. In: Laffranque J (ed) The protection of fundamental rights Post-Lisbon, Reports of the XXV FIDE Congress Tallinn 2012, vol 1. Tartu University Press, Tallinn, pp 141-215

Lenaerts K, Gutiérrez-Fons JA (2014) The charter in the EU constitutional edifice. In: Peers S, Hervey T, Kenner J, Ward A (eds) The EU charter of fundamental rights. A Commentary, Hart, Oxford, pp 1600-1637

Lenaerts K (2015) In Vielfalt geeint/Grundrechte als Basis des europäischen Integrationsprozesses. EuGRZ 42:353-361

Lerche P (1996) Achtung der nationalen Identität (Art. F Abs. 1 EUV). In: Bundesnotarkammer (ed) Festschrift für Helmut Schippel zum 65. Geburtstag, C.H. Beck, München, pp 919-932

Liisberg JB (2001) Does the EU charter of fundamental rights threaten the supremacy of community law? CML Rev 38:1171-1199

Lindner JF (2007a) Grundrechtsschutz gegen gemeinschaftsrechtliche Öffnungsklauseln—zugleich ein Beitrag zum Anwendungsbereich der EU-Grundrechte. EuZW 18:71-75

Lindner JF (2007b) Grundrechtsschutz in Europa-System einer Kollisionsdogmatik. EuR 42:160-193

Ludwigs M (2014) Kooperativer Grundrechtsschutz zwischen EuGH, BVerfG und EGMR. EuGRZ 41:273-285

Masing J (2006) Vorrang des Europarechts bei umsetzungsgebundenen Rechtsakten. NJW 59:264-268

Masing J (2015) Einheit und Vielfalt des Europäischen Grundrechtsschutzes. JZ 70:477-487

Masing J (2016) Unity and diversity of European fundamental rights protection. Eur Law Rev 41:490-512

Mayer FC, Lenski E, Wendel M (2008) Der Vorrang des Europarechts in Frankreich. EuR 43: $63-87$ 
Mayer FC (2009) Der Vertrag von Lissabon und die Grundrechte. EuR Suppl (EuR-Beiheft) 1/2009:87-102

Mayer FC, Wendel M (2014) Die verfassungsrechtlichen Grundlagen des Europarechts. In Hatje A, Müller-Graff P-C (eds) Enzyklopädie Europarecht. Europäisches Organisations- und Verfassungsrecht, vol 1. Nomos, Baden-Baden, § 4, pp 163-258

Nowag J (2016) EU law, constitutional identity, and human dignity: a toxic mix? Bundesverfassungsgericht: Mr R. CML Rev 53:1441-1453

Ohler C (2013) Grundrechtliche Bindungen der Mitgliedstaaten nach Art. 51 GRCh. NVwZ 32:1433-1438

Pernice I (2011) Der Schutz nationaler Identität in der Europäischen Union. AöR 136:185-221

Poli MD (2016) Der justizielle Pluralismus der europäischen Verfassungsgemeinschaft _ "Babylonische Gerichte" oder "Gerichte für Babylon". Der Staat 55:373-391

Reinbacher T, Wendel M (2016) Menschenwürde und Europäischer Haftbefehl—Zum ebenenübergreifenden Schutz grundrechtlicher Elementargarantien im europäischen Auslieferungsverfahren. EuGRZ 43:333-343

Rung J (2016) Grundrechtsschutz zwischen Verfassungsidentität und der Melloni-Rechtsprechung des EuGH. EWS 26:145-150

Sauer H (2016) "Solange" geht in Altersteilzeit—Der unbedingte Vorrang der Menschenwürde vor dem Unionsrecht. NJW 69:1134-1138

Seidel M (2003) Pro futuro: Kraft Gemeinschaftsrechts Vorrang des höheren einzelstaatlichen Grundrechtsschutzes? EuZW 14:97

Snell J (2015) Fundamental rights review of national measures: nothing new under the charter? Eur Public Law 21:285-308

Szczekalla P (2006) Grenzenlose Grundrechte. NVwZ 25:1019-1021

Thym D (2013) Die Reichweite der EU-Grundrechte-Charta-Zu viel Grundrechtsschutz? NVwZ 32:889-896

Thym D (2015) Vereinigt die Grundrechte! JZ 70:53-63

Trstenjak V, Beysen E (2013) The growing overlap of fundamental freedoms and fundamental rights in the case-law of the CJEU. Eur Law Rev 38:293-315

von Bogdandy A, Schill S (2010) Die Achtung der nationalen Identität unter dem reformierten Unionsvertrag. Zur unionsrechtlichen Rolle nationalen Verfassungsrechts und zur Überwindung des absoluten Vorrangs. ZaöRV 70:701-734

von Bogdandy A, Cruz Villalón P, Huber PM (eds) (2008) Handbuch Ius Publicum Europaeum. Offene Staatlichkeit - Wissenschaft vom Verfassungsrecht, vol 2. Heidelberg, C.F. Müller

von Bogdandy A, Kottmann M, Antpöhler C, Dickschen J, Hentrei S, Smrkolj M (2012) Ein Rettungsschirm für europäische Grundrechte. Grundlagen einer unionsrechtlichen Solange-Doktrin gegenüber Mitgliedstaaten. ZaöRV 72:45-78

von Danwitz T (2008) Funktionsbedingungen der Rechtsprechung des Europäischen Gerichtshofes. EuR 43:769-785

von Danwitz T (2009) Grundrechtsschutz im Anwendungsbereich des Gemeinschaftsrechts nach der Charta der Grundrechte. In: Herdegen M, Klein HH, Papier H-J, Scholz R (eds) Staatsrecht und Politik: Festschrift für Roman Herzog zum 75. Geburtstag (Essays in honour of Herzog). C. H. Beck, München, pp 19-34

von Danwitz T (2013) Verfassungsrechtliche Herausforderungen in der jüngeren Rechtsprechung des EuGH. EuGRZ 40:253-261

Voßkuhle A (2010) Der europäische Verfassungsgerichtsverbund. NVwZ 29:1-23

Walter C (2004) Grundrechtsschutz gegen Hoheitsakte internationaler Organisationen. Überlegungen zur Präzisierung und Fortentwicklung der Dogmatik des Maastricht-Urteils des Bundesverfassungsgerichts. AöR 129:39-80

Ward A (2014) Article 51-field of application. In: Peers S, Hervey T, Kenner J, Ward A (eds) The EU charter of fundamental rights. A Commentary, Hart, Oxford, p 1415

Weiler JHH, Fries SC (1999) A human rights policy for the European Community and Union: the question of competences. In: Alston P, Bustelo M, Heenan J (eds) The EU and human rights. Oxford University Press, Oxford, pp 147-165 
Wendel M (2011) Permeabilität im europäischen Verfassungsrecht. Mohr Siebeck, Tübingen

Wollenschläger F (2010) Die Gewährleistung von Sicherheit im Spannungsfeld der nationalen, unionalen und EMRK-Grundrechtsordnungen: Überlegungen zu Grundrechtsregimekonkurrenzen und ihrer Bewältigung im Europäischen Mehrebenensystem. In: Iliopoulos-Strangas J, Diggelmann O, Bauer H (eds) Rechtsstaat, Freiheit und Sicherheit in Europa. Societas Iuris Publici Europaei, vol. 6. Nomos, Athen/Baden-Baden/Brüssel, pp 45-88

Wollenschläger F (2014a) Grundrechtsschutz und Unionsbürgerschaft. In: Hatje A, Müller-Graff P-C (eds) Enzyklopädie Europarecht. Europäisches Organisations- und Verfassungsrecht, vol. 1. Nomos, Baden-Baden, $\S 8$, pp 367-475

Wollenschläger F (2014b) Anwendbarkeit der EU-Grundrechte im Rahmen einer Beschränkung von Grundfreiheiten. Bestätigung der ERT-Rechtsprechung durch den EuGH auch unter der Grundrechtecharta. EuZW 25:577-580

Wollenschläger F (2015a) The EU charter of fundamental rights and its applicability to the member states - a step towards unitarisation or federalisation? Ritsumeikan Int Aff 13:1-11

Wollenschläger F (2015b) Art. 23 GG. In: Dreier H (ed) Grundgesetz Kommentar: GG, vol 2, 3rd edn. Mohr Siebeck, Tübingen, pp 436-551

Wollenschläger F, Krönke L (2016) Telekommunikationsüberwachung und Verkehrsdatenspeicherung — eine Frage des EU-Grundrechtsschutzes? NJW 69:906-910

\section{Author Biography}

Ferdinand Wollenschläger (* 1976) Chair for Public Law, European Law and Public Economic Law at the University of Augsburg (Germany), Faculty of Law (since 2011).

Law studies at Munich and Oxford (Brasenose College) Universities; fully qualified German lawyer (1st and 2nd State Examination, 2002 and 2004 respectively). Ph.D. (2006, Munich University) with dissertation "Grundfreiheit ohne Markt. Die Herausbildung der Unionsbürgerschaft im unionsrechtlichen Freizügigkeitsregime" (A new fundamental freedom beyond market integration. The emergence of European Union citizenship in the regime of the free movement of persons; republished 2017); awarded with the Faculty prize of Munich Law Faculty and with the Ph.D. prize of the Munich law society. "Habilitation" (second Ph.D., 2010) on "Verteilungsverfahren" (Distributing scarce goods as a task of the administration: parameters of constitutional and European Union law, administrative procedures in specific areas \& the emergence of a new type of administrative procedure), again at the Faculty of Law of Munich University. Both, Ph.D. and Habilitation, were supervised by Professor Peter M. Huber, Justice of the Federal Constitutional Court.

2004: research Scholar with Prof. Joseph H. H. Weiler at the Jean Monnet Center for Regional and International Economic Law and Justice at New York University, School of Law; 2012/2013: guest professorship at the Leiden Law Faculty (NL). 2014: national rapporteur on Public Procurement law for the XXVI FIDE Congress (Fédération Internationale pour le Droit Européen) held in Copenhagen; 2015: lecture at the 75th Staatsrechtlehrertagung on "Verfassung im Allgemeinen Verwaltungsrecht: Bedeutungsverlust durch Europäisierung und Emanzipation?" (Constitutionalisation and deconstitutionalisation of Administrative Law in view of Europeanisation and Emancipation).

Co-editor of the Europäische Zeitschrift für Wirtschaftsrecht (European Review for Economic Law) and of the book series "Beiträge zum Verwaltungsrecht" (Contributions to Administrative Law, Mohr Siebeck); co-speaker of the German-Italian conference of Public Lawyers and member of the European Group of Public Law.

Legal expert on constitutional, administrative and EU law issues for the European Parliament, European Commission, the German Bundestag, the German Bundesrat and various Parliaments of the German Länder. 
Open Access This chapter is licensed under the terms of the Creative Commons Attribution-NonCommercial-NoDerivatives 4.0 International License (http://creativecommons. org/licenses/by-nc-nd/4.0/), which permits any noncommercial use, sharing, distribution and reproduction in any medium or format, as long as you give appropriate credit to the original author (s) and the source, provide a link to the Creative Commons license and indicate if you modified the licensed material. You do not have permission under this license to share adapted material derived from this book or parts of it.

The images or other third party material in this chapter are included in the chapter's Creative Commons license, unless indicated otherwise in a credit line to the material. If material is not included in the chapter's Creative Commons license and your intended use is not permitted by statutory regulation or exceeds the permitted use, you will need to obtain permission directly from the copyright holder. 